Journal of Epidemiology and Public Health (2019), 4(3): 156-170

https://doi.org/10.26911/jepublichealth.2019.04.03.02

\title{
Multilevel Analysis on the Contextual Effect of Village on the Incidence of Hemorrhagic Dengue Fever in Grobogan, Central Java
}

\author{
Ambar Sari'), Setyo Sri Rahardjo²), Endang Sutisna Sulaeman²) \\ 1)Masters Program in Public Health, Universitas Sebelas Maret \\ ${ }^{2)}$ Faculty of Medicine, Universitas Sebelas Maret
}

\begin{abstract}
Background: Dengue hemorrhagic fever (DHF) is a disease caused by dengue virus through the bite of the Aedes aegypti mosquito. DHF is an endemic disease in more than 100 countries. There were 728 cases of DHF and 8 cases of death in Grobogan, Central Java, in 2017. The purpose of this study was to examine the contextual effect of village on the incidence of DHF.

Subjects and Method: This was a case control study conducted in Grobogan, Central Java, from November to December 2018. A sample of 200 study subjects was selected by fixed disease sampling. The dependent variable was DHF. The independent variables were the presence of water shelter, ponds, farm land, mosquito larvae, hanging clothes, house density, eradication of mosquito nest, education, and employment. The data were collected by questionnaire and observation. The data were analyzed by a multilevel logistic regression.

Results: Existence of water shelter $(b=4.53 ; 95 \% C I=1.29$ to $7.76 ; p=0.006)$, ponds $(b=2.71$; $95 \% \mathrm{CI}=0.26$ to $5.17 ; \mathrm{p}=0.030)$, farm land $(\mathrm{b}=3.40 ; 95 \% \mathrm{CI}=0.52$ to $6.28 ; \mathrm{p}=0.021)$, mosquito larvae $(b=3.45 ; 95 \% C I=0.61$ to $6.29 ; p=0.017)$, hanging clothes $(b=2.39 ; 95 \% C I=0.23$ to 4.56 ; $\mathrm{p}=0.030)$, and house density $(\mathrm{b}=5.55 ; 95 \% \mathrm{CI}=1.59$ to $9.51 ; \mathrm{p}=0.006)$, increased the risk of DHF. Education $\geq$ senior high school $(b=-4.79 ; 95 \% \mathrm{CI}=-8.44$ to $-1.13 ; \mathrm{p}=0.010)$, employed $(\mathrm{b}=-5.36$; 95\% CI= -9.22 to $-1.49 ; \mathrm{p}=0.006)$, and exposed to DHF mosquito nest eradication program $(\mathrm{b}=-$ $4.31 ; 95 \% \mathrm{CI}=-7.64$ to $-0.97 ; \mathrm{p}=0.011$ ) decreased the risk of DHF. Village environment had strong contextual effect on DHF with ICC $=51.33 \%$.

Conclusion: Existence of water shelter, ponds, farm land, mosquito larvae, hanging clothes, and house density, increase the risk of DHF. Education $\geq$ senior high school, employed, and exposed to DHF mosquito nest eradication program decrease the risk of DHF. Village environment has strong contextual effect on DHF.
\end{abstract}

Keywords: dengue hemorrhagic fever, environmental factors, eradication of mosquito nests, village strata, multilevel analysis

\section{Correspondence:}

Ambar Sari. Masters Program in Public Health. Universitas Sebelas Maret, Jl. Ir. Sutami 36A, Surakarta 57126, Central Java, Indonesia. Email: ambarsari69.as@gmail.com.

Mobile: +625647847180; 08562623045

\section{BACKGROUND}

Dengue hemorrhagic fever (DHF) is a disease caused by the dengue virus that is transmitted from person to person through the bite of the Aedes aegypti mosquito. DHF is often found mainly in the tropics and causes extraordinary events (KLB). The emergence of this disease is related to environmental conditions and people's behavior (Ministry of Health of the Republic of Indonesia, 2017).

Based on data on the average number of dengue cases reported to WHO in the period 2004-2010, from 30 countries endemic to DHF, Indonesia was ranked second with an average number of cases of 129,435 cases, below Brazil which was ranked first with 447,446 case, so that Indonesia is the 
country with the highest number of cases of dengue fever in Asia (World Health Organization, 2012).

The number of dengue cases in Indonesia in 2017 was 59,047 cases with 444 deaths. The number of dengue cases in 2017 decreased compared to the number of cases in $2016(204,171)$ cases. The number of deaths due to dengue in 2017 also decreased from 2016 (1,598 deaths). Incidence Rate (IR) or dengue morbidity rate in 2017 also decreased from 2016, which is 50.75 to 22.55 per 100,000 population. And, the Case Fatality Rate (CFR) also declined from $0.78 \%$ in 2016 to $0.75 \%$ in 2017 (RI Ministry of Health, 2018).

DHF is a serious problem in Central Java Province, it is proven that 35 districts/ cities have been infected with dengue. Incidence Rate (IR) of DHF in Central Java Province in 2017 amounted to 21.60 per 100,000 population, a decrease compared to 2016 which was 43.4 per 100,00o population. Regency / city with the highest IR DBD is Magelang District 54.33 per 100,000 inhabitants, and the second is Grobogan district of 48.12 per 100,000 population and the lowest is Rembang 2.07 per 100,000 population. The mortality rate/ Case Fatality Rate (CFR) in Central Java in 2017 was 1.24 percent, decreasing compared to the CFR in 2016, which was 1.46 percent. The highest mortality rate is found in Tegal district at 3.45 percent and there are 21 districts / cities with CFR> 1 percent. (Central Java Provincial Health Office, 2017)

Grobogan Regency is one of the endemic areas of dengue in the province of Central Java. DHF cases occur repeatedly in this area every year, even though every year health personnel try to eradicate this disease through a DHF prevention program. In Grobogan district in 2017, there were 728 cases of dengue fever, 8 people reported dead. It decreased when compared to 2016 as there were 1,390 cases reported with the death of 18 cases. This is caused by one of the environmental factors of DHF sufferers, namely water reservoirs, mosquito larvae, hanging clothes, house density, PSN movements that are not carried out continuously (Grobogan District Health Office, 2017).

Factors that influence the incidence of dengue include host factors, the environment, clean and healthy life behaviors, and their own viral factors. Environmental factors are the main determining factors in dengue transmission. Environmental factors, include the biological, physical and socio-economic environment that support mosquitoes breed (Sarfraz et al., 2014). Environmental factors that influence the spread of dengue cases include: physical environmental factors are the existence of a Water Shelter (TPA), the presence of clothes hanging, the presence of houses; Biological environmental factors are the existence of farm land, the existence of mosquito larvae, and the existence of ponds; socioeconomic environmental factors are continuity of PSN, education, and employment (Nurrochmawati, et al., 2017; Francisco, et al., 2017; Diaz-Quijano et al., 2018; Phuong et al., 2008).

The village is a legal community unit that has territorial limits that are authorized to regulate and manage government affairs, the interests of the local community based on community initiatives, origin rights, and/ or traditional rights recognized and respected in the system of government of the Unitary State of the Republic of Indonesia. In Permendagri Number 84 of 2015 concerning the Organizational Structure of the Village Government adjusted to the level of village development, namely Swasembada, Swakarya, and Swadaya Village (Kemendagri, 2015). 
Journal of Epidemiology and Public Health (2019), 4(3): 156-170

https://doi.org/10.26911/jepublichealth.2019.04.03.02

Based on the description above, the researcher is interested in knowing the influence of the environment (physical, biological, and socio-economic), the Movement to Eradicate Mosquito Nests in the context of the village against the incidence of Dengue Hemorrhagic Fever in Grobogan Regency.

\begin{tabular}{l} 
SUBJECTS AND METHOD \\
\hline 1. Study Design \\
This study was an analytic observational \\
study with a case control design. The study \\
was conducted from November to Decem- \\
ber 2018.
\end{tabular}

\section{Population and Samples}

The study population was all residents in Grobogan, Central Java. A sample of 200 study subjects was selected by fixed disease sampling.

\section{Study variables}

The dependent variable was the incidence of DHF. The independent variables were water reservoirs, hanging clothes, house density, farm land, mosquito larvae, ponds, education, employment, and mosquito eradication program.

\section{Operational definition of variables}

Dengue Hemorrhagic Fever (DHF) was defined as an infectious disease caused by the dengue virus and is transmitted by the Aedes aegypti mosquito, which is characterized by sudden fever 2 to 7 days without a clear cause. Doctor's diagnosis tool was done by anamnesa, physical examination, and laboratory examination (platelets, HT A, and HT B) which states the patient is affected by dengue. The measurement scale was categorical, coded o for not DHF and 1 for DHF.

The existence of a water reservoir (TPA) was defined as being found in a water reservoir either in the house or outside the house in an open condition that has the potential to become a breeding place for mosquitoes as measured by the observation sheet. The measurement scale was categorical, coded o for no and 1 for yes.

The existence of hanging clothes is defined as found clothes that are hung in the house (not in cupboards) as measured by questionnaires and observation sheets. The categorical measurement scale of data analysis is changed to dichotomy, $\mathrm{O}=$ none, $1=$ exists.

The density of residents' houses which are close to a distance of less than 100 meters causes mosquitoes to easily move from one house to another as measured by a questionnaire. The categorical measurement scale of data analysis was changed to dichotomy, $o=$ not solid ( $\geq 100$ meters), 1 $=\operatorname{solid}(<100$ meters $)$.

The existence of a plot of land is defined as a plot of land located directly around the house and clearly demarcated, planted with one or various types of plants that affect the lighting and humidity around the house. The measuring instrument is a questionnaire, the measuring scale is categorical for data analysis which is then converted into a dichotomy with $\mathrm{o}=$ found plants ( $<14$ trees), $1=$ found plants $(\geq 14$ trees).

The existence of mosquito larvae is defined as mosquito larvae which are found both in the home or outside the home in water shelter such as bathtub/ toilet, drum/ barrel/jar, waste water from the refrigerator/ dispenser, can/used tires around the house. The measuring instruments are questionnaire and observation sheet. The measurement scale was categorical, coded o for no larvae and 1 for yes.

The existence of a pond is defined as a pond around the respondent's house which is a place for breeding mosquitoes. The measuring instrument is a questionnaire. The measuring scale is categorical for data 
analysis to be converted into a dichotomy with $0=$ not found, $1=$ found.

Education is defined as the last level of formal education that the respondent has ever taken. The measuring scale is categorical for data analysis to be converted into dichotomy, $\mathrm{o}=$ low (SD-SMP), $1=$ high (high school, diploma, bachelor, master and doctorate).

Job is defined as the type of work the respondent does on a daily basis. The measuring scale is categorical for data analysis to be converted into a dichotomy with $\mathrm{O}=$ not working, $1=$ working .

The Mosquito Nest Eradication Movement (PSN) is defined as an activity carried out by research subjects $\leq$ once a week to eradicate mosquito nests in places that make it possible to become a place for mosquitoes to lay eggs, in the form of $3 \mathrm{M}$ plus. The measurement scale is categorical for analysis of the data converted into dichotomy, $\mathrm{o}=\mathrm{bad}$, if the number of correct answers answered by the research subject is $<6,1=$ good, if the number of correct answers answered by the research subject $\geq 6$.

\section{Data Analysis}

Data processing includes editing, coding, scoring, tabulating. Data analysis techniques include univariate analysis which aims to display data in the form of frequency distribution. Bivariate analysis uses Chi Square for dichotomous variables to see the significance of the relationship between each dependent and independent variable. Multivariate analysis of logistic regression was carried out using a multilevel approach aims to measure the influence of more than one independent variable on the dependent variable.

\section{Research Ethics}

Researchers pay attention to the ethics of research, namely giving informed consent, anonymity, confidentiality, and Ethical clearance (Health Research Ethics Commission (KEPK), Faculty of Medicine, Sebelas Maret University Number: 352 / UN27.6 / KEPK / 2018 with Protocol number: 01/18/11 / 357).

\section{RESULTS}

\section{Univariate Analysis}

The subjects in this study were infants, toddlers, children, adolescents, adults, and the elderly of all ages spread in Grobogan Regency. The subjects of the study were 200 people consisting of 50 people in the case group (diagnosed with dengue in January 2018 - September 2018) and 150 people in the control group (neighboring cases who had never been diagnosed with DHF at the same time). The results showed that on gender characteristics, the case group was $64 \%$ (32 subjects) male sex, and $36 \%$ cases (18 subjects) were female. Based on table 1 , there are 122 subjects (81.3\%) in the control group where there is no landfill which has the potential to become a breeding ground for mosquitoes. Different results were shown in the case group amounting to 29 subjects (58\%) found the presence of landfill which could potentially be a place for breeding mosquitoes. The variable presence of hanging clothes was not found in the control group subjects of 124 subjects (82.7\%) compared to the case group of 20 subjects (40\%). At residence density variables, more houses were found in the case group of 27 subjects (54\%) than in the control group of 25 subjects (16.7\%).

Likewise, the presence of land in the control group amounting to 115 subjects (76.7\%) was not found in the home garden plants and in the case group of 24 subjects (48\%) no plants were found in the home garden. In the variable presence of mosquito larvae in the control group amounting to 120 subjects (80\%) more 
Journal of Epidemiology and Public Health (2019), 4(3): 156-170

https://doi.org/10.26911/jepublichealth.2019.04.03.02

were not found in the presence of mosquito larvae than in the case group. In the variable pool presence in the control group amounting to 118 subjects (78.7\%) did not find more pool than in the case group.

In the education variable in the control group, 116 subjects (77.3\%) were highly educated. Different results were shown in the case group with 27 subjects
(54\%) having low education. In the occupational variables in the control group, there were 115 subjects (76.7\%) who worked. This is different from the results in the case group where 26 (52\%) of them did not work. In the PSN movement variable, DHF, most of the control group subjects were good, namely 126 subjects ( $84 \%)$.

Table 1. Research Characteristics of Case Categorical Data and Control

\begin{tabular}{|c|c|c|c|c|}
\hline \multirow{3}{*}{ Variable } & \multicolumn{4}{|c|}{ DHF incidence } \\
\hline & \multicolumn{2}{|c|}{ DHF $(n=50)$} & \multicolumn{2}{|c|}{ Not DHF $(n=150)$} \\
\hline & $\mathbf{n}$ & \% & $\mathbf{N}$ & $\%$ \\
\hline \multicolumn{5}{|c|}{ Existence of Water Shelter } \\
\hline Not found & 21 & 42 & 122 & 81.3 \\
\hline Found & 29 & 58 & 28 & 18.7 \\
\hline \multicolumn{5}{|c|}{ The existence of hanging clothes } \\
\hline Not found & 20 & 40 & 124 & 82.7 \\
\hline Found & 30 & 60 & 26 & $17 \cdot 3$ \\
\hline \multicolumn{5}{|l|}{ Residence Density } \\
\hline Not dense & 23 & 46 & 125 & 83.3 \\
\hline Dense & 27 & 54 & 25 & 16.7 \\
\hline \multicolumn{5}{|l|}{ The existence of a yard } \\
\hline Not found & 24 & 48 & 115 & 76.7 \\
\hline Found & 26 & 52 & 35 & 23.3 \\
\hline \multicolumn{5}{|c|}{ The existence of mosquito larvae } \\
\hline No & 17 & 34 & 120 & 80 \\
\hline Yes & 33 & 66 & 30 & 20 \\
\hline \multicolumn{5}{|l|}{ The existence of a pond } \\
\hline Not found & 24 & 48 & 118 & 78.7 \\
\hline Found & 26 & 52 & 32 & 21.3 \\
\hline \multicolumn{5}{|l|}{ Education } \\
\hline Low & 27 & 54 & 34 & 22.7 \\
\hline High & 23 & 46 & 116 & $77 \cdot 3$ \\
\hline \multicolumn{5}{|l|}{ Occupation } \\
\hline Not working & 26 & 52 & 35 & $23 \cdot 3$ \\
\hline Working & 24 & 48 & 115 & 76.7 \\
\hline \multicolumn{5}{|l|}{ PSN Movement } \\
\hline Poor & 23 & 46 & 24 & 16 \\
\hline Good & 27 & 54 & 126 & 84 \\
\hline
\end{tabular}

\section{Bivariate Analysis}

Bivariate analysis was used to see the relationship of independent variables (Landfill existence, presence of hanging clothes, house density, presence of yard, existence of mosquito larvae, presence of ponds, education, work, and Mosquito Nest Eradication movement) with dependent variable (incidence of dengue).

Table 2 shows a relationship between the presence of TPA ( $p<0.001$; OR $=6.02 ; 95 \%$
$\mathrm{CI}=3.00$ to 12.06$)$, the presence of hanging clothes ( $\mathrm{p}<0.001$; OR $=7.15 ; 95 \%$ $\mathrm{CI}=3.53$ to 14.50$)$, house density ( $\mathrm{p}$ $<0.001 ; \mathrm{OR}=5.87 ; 95 \% \mathrm{CI}=2.91$ to 11.85 ), presence of farm land $(\mathrm{p}<0.001 ; \mathrm{OR}=$ 3.56; $95 \% \mathrm{CI}=1.82$ to 6.97 ), presence of mosquito larvae ( $\mathrm{p}<0.001 ; \mathrm{OR}=7.76 ; 95 \%$ $\mathrm{CI}=3.82$ to 15.77$)$, the presence of ponds ( $\mathrm{p}<0.001 ; \mathrm{OR}=3.99 ; \mathrm{CI} 95 \%=2.03$ to 7.87), education ( $\mathrm{p}<0.001$; $\mathrm{OR}=0.25 ; 95 \%$ $\mathrm{CI}=0.13$ to 0.49$)$, employment $(\mathrm{p}<0.001$; 
$\mathrm{OR}=0.28 ; 95 \% \mathrm{CI}=0.14$ to 0.55$)$, and PSN movements ( $\mathrm{p}<0.001$; OR $=0.22$; CI
$95 \%=0.11$ to 0.45$)$ to the incidence of dengue disease and statistically significant.

Table 2. Bivariate analysis

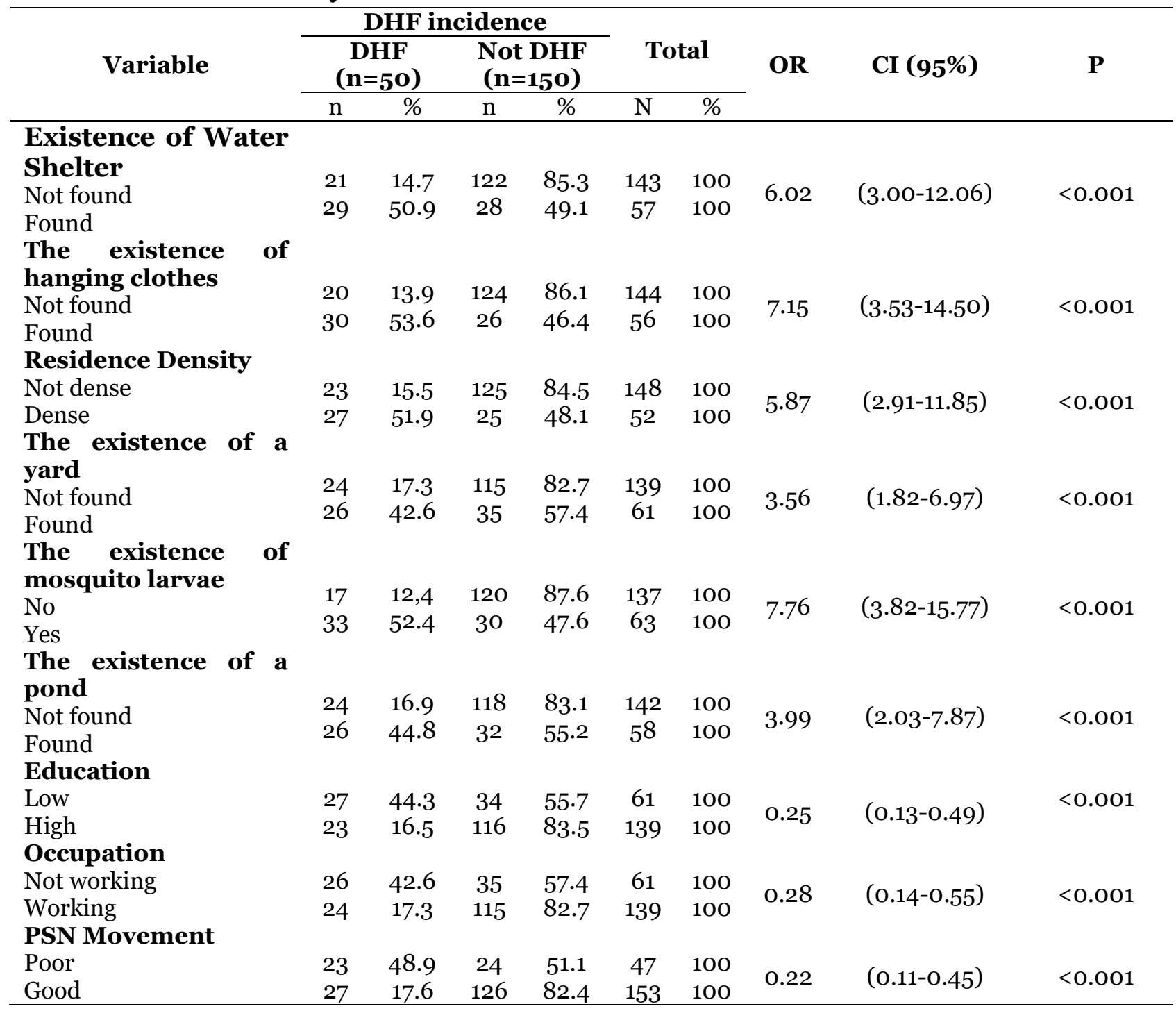

\section{Multivariate Analysis}

Multivariate analysis explains the influence of more than one independent variable on one dependent variable. In table 3 , it showed that there was an effect of the presence of WR on the incidence of HDF. The subject who have WR that has the potential to became a breeding place for mosquitoes has a log odds of suffering from HDF by 4.53 units higher than those who did not have potential WR $(b=4.53 ; 95 \%$ $\mathrm{CI}=1.29$ up to $7.76 ; \mathrm{p}=0.006)$.
There was an effect of the presence of hanging clothes on the incidence of HDF. The subject who have hanging clothes have a log odds of suffering from HDF by 2.39 units higher than subject who did not have hanging clothes $(b=2.39 ; 95 \% \mathrm{CI}=0.23$ up to 4.56 ; $\mathrm{p}=0.030$ ).

There was an effect of house density on the incidence of HDF. Subjects with a dense distance of houses (<100 meters) have log odds for suffering from HDF by 5.55 units higher than subjects who did not 
Journal of Epidemiology and Public Health (2019), 4(3): 156-170

https://doi.org/10.26911/jepublichealth.2019.04.03.02

have house density ( $\geq 100$ meter) ( $b=5.55$; $95 \% \mathrm{CI}=1.59$ up to $9.51 ; \mathrm{p}=0.006)$.

There was an effect of the presence of yard area on the incidence of HDF. Subjects who have plants in the house yard of $\geq 14$ trees have log odds for suffering from HDF by 3.40 units higher than subjects who have plants in the house yard of $<14$ pohon $(\mathrm{b}=$ $3.40 ; 95 \% \mathrm{CI}=0.52$ up to $6.28 ; \mathrm{p}=0.021$ ).

\section{Table 3. Multilevel logistic regression}

\begin{tabular}{|c|c|c|c|c|}
\hline \multirow[b]{2}{*}{ DHF Incidence } & \multirow{2}{*}{$\begin{array}{c}\text { Regression } \\
\text { coefficient } \\
\text { b } \\
\end{array}$} & \multicolumn{2}{|c|}{ CI 95\% } & \multirow[b]{2}{*}{$\mathbf{p}$} \\
\hline & & $\begin{array}{c}\text { Lower } \\
\text { Level }\end{array}$ & $\begin{array}{l}\text { Upper } \\
\text { Level }\end{array}$ & \\
\hline \multicolumn{5}{|l|}{ Fixed Effect } \\
\hline \multicolumn{5}{|l|}{ Existence of Water Shelter (found) } \\
\hline The existence of hanging clothes (found) & 4.53 & 1.29 & 7.76 & 0.006 \\
\hline Residence Density (dense $<100$ meter) & 2.39 & 0.23 & 4.56 & 0.030 \\
\hline The existence of a yard ( $\geq 14$ trees) & $5 \cdot 55$ & 1.59 & 9.51 & 0.006 \\
\hline The existence of mosquito larvae & $3 \cdot 40$ & 0.52 & 6.28 & 0.021 \\
\hline ( $\geq 1$ flick) & 3.45 & 0.61 & 6.29 & 0.017 \\
\hline The existence of a pond (found) & 2.71 & 0.26 & 5.17 & 0.030 \\
\hline Education ( $\geq$ senior high school) & $-4 \cdot 79$ & -8.44 & -1.13 & 0.010 \\
\hline Occupation (working) & $-5 \cdot 36$ & -9.22 & -1.49 & 0.007 \\
\hline DHF PSN Movement (good) & $-4 \cdot 31$ & -7.64 & -0.97 & 0.011 \\
\hline \multicolumn{5}{|l|}{ Random Effect } \\
\hline Variation of village strata constants & 3.47 & 0.41 & 28.85 & \\
\hline \multicolumn{5}{|l|}{$\mathrm{N}$ observation $=200$} \\
\hline \multicolumn{5}{|l|}{ Average $=8, \min =8$, maks $=8$} \\
\hline \multicolumn{5}{|l|}{ Log likelihood $=-30.65$} \\
\hline LR test vs. Regresi logistik, $p=0.029$ & & & & \\
\hline $\mathrm{ICC}=51,33 \%$ & & & & \\
\hline
\end{tabular}

There was an effect of the presence of pond on the incidence of HDF. Subjects who have pond around the house have a log odds of suffering from HDF by 2.71 higher than subjects who did not have pond around their houses $(b=2.71 ; 95 \% \mathrm{CI}=0.26$ up to 5.17 ; $=0.030$ ).

There was an effect of education on the incidence of HDF. Subjects with high level of education $(\geq \mathrm{HS}$ ) have a log odds of suffering from HDF by 4.79 units higher than subjects with low level of education (ES-JHS) $(b=-4.79 ; 95 \% \mathrm{CI}=-8.44$ up to 1.13; $\mathrm{p}=0.010)$.

There was an effect of employment on the incidence of HDF. Subjects who worked around the house have a log odds of suffering from HDF by 5.36 units higher
There was an effect of the presence of the presence of mosquito larvae on the incidence of HDF. Subject who have house with mosquito larvae have log odds for suffering from HDF by 3.45 units higher than subjects who did not have mosquito larvae $(b=3.45 ; 95 \% \mathrm{CI}=0.61$ up to 6.29 ; $\mathrm{p}=0.017)$. than subjects who did not work around the
house $(b=-5.36 ; 95 \% \mathrm{CI}=-9.22$ up to -1.49 ;
$\mathrm{p}=$ 0.006). incidence of HDF. Subjects who conduct MNE have a log odds of suffering from HDF by 4.31 unit lower than subjects who did not do MNE $(b=-4.31 ; 95 \% \mathrm{CI}=-7.64$ up to -0.97; $\mathrm{p}=0.011$ ).

In the analysis of the data, the score of ICC $=51.33 \%$. The indicator showed that the village conditions in each strata have a contextual influence on the incidence of HDF by $51.33 \%$. This number was greater effect of the village strata shown from multilevel analysis was very important to note. The table also showed that $\mathrm{p}=0.029$. This mean that there were significant 
differences between the models without calculating the contextual effect and models that calculate the contextual effect.

\section{DISCUSSIONS}

\section{The effect of water reservoir on the incidence of HDF}

The result of this study showed that there was an effect of water reservoir availability on the incidence of HDF which was statistically significant in bivariate and multivariate tests. This illustrated that the presence of WR in the home environment in open conditions has the potential to became a place for mosquitoes to breed so that it can cause the incidence of HDF. The existence of a water reservoir/breeding place would create opportunities for the aedes aegypti mosquito to breed. This was because most of the life cycles of mosquitoes (eggs, larvae and pupae) occurred in the water. Mosquitoes that breed around the house would be easier to reach humans (hosts), therefore, the presence of water reservoirs around the house would increase the incidence of HDF (Rendy, 2013).

The existence of containers/reservoirs has the potential to reproduce vectors in contact with human as hosts. The endemicity of HDF disease was affected by the presence of aedes aegypti mosquito larvae in containers/water reservoirs, especially those which used for human needs (Barrera, et al., 2011).

This study supported the research of Sukowinarsih and Cahyati in Semarang which stated that the larvae at the water reservoir (TPA) can affect the incidence of dengue by 3.38 times greater for experiencing DHF (Sukowinarsih and Cahyati, 2010). The results of research conducted by Nurrochmawati, et al (2017) showed that there was a relationship of the presence of WR with no cover that have the potential to became a place for mosquitoes to breed that was $\mathbf{1 1 . 4 2}$ times more likely to suffer from HDF. The presence of WR played an important role in the density of the Aedes aegypti mosquito vector, because more and more WR sites would increase the breeding places and would be more densely populated by the Aedes aegypti mosquito (Dash et al., 2012).

\section{The effect of hanging clothes on the incidence of $\mathrm{HDF}$}

The result of this study showed that there was an effect of hanging clothes on the incidence of HDF which was statistically significant in bivariate and multivariate tests. This showed that hanging clothes affected the incidence of HDF. It mean that the subjects who have hanging clothes in the houses were more likely to experience HDF than those who did not have hanging clothes inside the house.

Clothes were a clothing requirement for every human being and the existence was never separated from human life. However, handling clothes after using was often ignored. Just as the habit of hanging clothes can increase the number of mosquitoes in the house because mosquitoes prefer to perch on hanging clothes. Based on research conducted by Nurrochmawati (2017) in Nganjuk, it showed that the people who have hanging clothes were more likely to have HDF than subjects who did not have hanging clothes inside their houses.

This study was in line with a study done by Sukowinarsih and Cahyati (2010) in Semarang which stated that the presence of hanging clothes in the house have 4.405 times greater to be infected by HDF. Furthermore, a study done by Dinata and Dhewantara (2012) stated that hanging clothes affected the incidence of HDF by $80 \%$ in endemic area.

Aedes Aegypti mosquito rested on the clothes that have been used which were 
Journal of Epidemiology and Public Health (2019), 4(3): 156-170

https://doi.org/10.26911/jepublichealth.2019.04.03.02

hanging in the room, because there were several substances that can attract the mosquitoes such as amino acids, lactic acid, and other substances. Mosquitoes were attracted to the scent of the human body because carbon dioxide from breathing was then attached to the clothes. Furthermore, if the clothes were hung, it would increase the mosquito population in the house (Soetaryo, 2004). Based on a study done by Amrieds et al. (2016) it showed that respondents who still have the habit of hanging clothes have a chance of getting HDF than respondents who did not have the habit of hanging clothes. Clothes that should hang behind the door and on the walls of the room or house should be stored in a closet while the dirty clothes should be washed immediately, because the aedes aegypti mosquitoes like to perch and rest in dark places and hanging clothes.

\section{The effect of house density on the incidence of HDF}

The result of this study showed that there was an effect of house density on the incidence of HDF which was statistically significant in bivariate and multivariate tests. This showed that density of houses with a distance of less than 100 meters based on the distance of flying mosquitoes have a chance to be affected by HDF.

House density of Aedes aegypti mosquito was a mosquito with a short fly distance (100 meters). Therefore, the mosquito was domestic. If the houses were close, mosquitoes can easily move from one house to another. If the occupants of one of the houses were affected by HDF, then the virus can be transmitted to their neighbors (Wati, 2009).

The result of a study done by Affandy (2018), showed that there was a relationship between house density and the incidence of HDF. Based on the chi square test that has been done, the score of $\mathrm{P}$ was
0.002, this score was smaller than the score of a significant level of 0.05. So, it can be concluded that there was a relationship between the density of houses with the incidence of Dengue Fever in the Bengkuring City Health Center area of Samarinda with a significant score which was smaller than $5 \%(\mathrm{p}=0,002<\alpha=0,05)$.

According to Adityama (2011), the condition of the house's physical environment that did not fulfill the requirements provided a great opportunity for the occurrence of HDF, where the condition of the house based on house density would also affect the environmental density that can facilitate the transmission in the area because mosquitoes fly 50-100 meters, so it was easier for aedes aegypti mosquito to move from one house to another. Adjacent houses have a high risk of HDF because of the short distance of aedes aegypti's flying distance which was 100 meters (Yatim, 2011).

\section{The effect of farm land on the incidence of HDF}

The result of this study showed that there was an effect of yard area on the incidence of HDF which was statistically significant in bivariate and multivariate tests. The yard was a piece of land that was located directly around the house, planted with one or various types of plants and still has ownership relations with the house concerned. Plants that were usually planted in the yard were plants that have thick leaves and fruits such as palm trees, mango trees, star fruit trees and others (Dinata et al., 2012).

This result was supported by a study done in Vietnam in 2008 by Phuong., et al (2008) which showed that one of the five variables studied, the presence of many plants near the house was a factor that influenced the incidence of HDF (RR 2.22; 95\% CI 1.18-4.17). Furthermore, a study of 
Winarsih (2011) in Semarang stated that statistically, there was a relationship between the existence of plants and the incidence of HDF. This was in accordance with the theory of Soegijanto (2003) which stated that the number of plants around the house affected the humidity and lighting of the house and was a place for the mosquitoes to perch and breed. Therefore, the number of plants in the yard would provide the place that mosquitoes liked to perch and increase the age of mosquitoes (Dhillon, 2008). According to research done by Brigit et al., (2004) cited by Wahyono et al., (2010), if the number of plants in the yard of the house $\geq 14$ trees, it has a greater likelihood of being affected by HDF.

Based on a study done by Francisco (2017) it showed that there was a significant relationship between the existence of yard area and the incidenc of HDF in the working area of Tikala Baru health center. From the result of analysis, the score of $\mathrm{OR}=1,333$ and $95 \% \mathrm{CI}=$ $0,133-1.835$, therefore, the existence of yard was a risk factor, meaning that someone who owned a yard area would have 1.3 times higher risk to have HDF compared to people who did not have a yard.

Dinata and Dhewantara (2012) in their study found that the existence of yard: high endemic area (98\%), moderate endemic (75\% and 95\%) and low endemic (100\%).

\section{The effect of mosquito larvae on the incidence of HDF}

The result of this study showed that there was an effect of mosquito larvae on the incidence of HDF which was statistically significant in bivariate and multivariate tests. The result showed that in the environment where mosquito larvae were found, it has a higher likelihood of DHF.
Water Reservoir (WR) with a long puddles were usually contained of pathogenic bacteria from parasites that affected larva growth. Aedes aegypti mosquito liked to breed in clear water that was not directly related to the soil and has dark color. The existence of larvae can be found inside and outside the house on WR such as bathtubs/toilets, barrels, jars, dispensers, used bottles, used tires, etc. which were places that can hold the puddles (Phuong et al., 2008).

After 6-8 hours a day becoming a larva, it developed into a cocoon and 2 days later it became an adult mosquito (breeding from eggs - larvae - cocoons - mosquitoes needed 7-10 days). Within 1-2 days, newly hatched mosquitoes (which were females) would bite humans and were ready to mate with male mosquitoes. When they sucked the blood from a HDF sufferer, this mosquito can transmit the virus for the rest of its life. So that the existence of a mosquito form must be controlled. Because the right HDF control was to terminate the chain of transmission that was by controlling the vector (brunkard et al., 2007; Fathi et al., 2005; Schaffner and Mathis, 2014).

Based on a study done by Nurrochmawati (2017) it showed that there was an effect of mosquito larvae on the incidence of HDF which was statistically significant in bivariate and multivariate tests. The result showed that in the environment where mosquito larvae were found, it has a higher likelihood of DHF. This result was in line with a study done by Sunaryo \& Pramestuti (2014) in four endemic DHF districts/cities in Central Java, namely Grobogan, Purbalingga, Kendal, and Semarang City, which showed that increased DHF cases in the four districts/cities were affected by an agent which was the aedes aegypti mosquito 
vector. Where the increase in the number of WR with larva affected the increase in HDF cases (Sunaryo \& Pramestuti, 2014).

\section{The effect of pond on the incidence of HDF}

The result of this study showed that there was an effect of pond on the incidence of HDF which was statistically significant in bivariate and multivariate tests. The results showed that the existence of ponds around the house has a higher likelihood of HDF.

Based on a study conducted by Francisco (2017) it showed that there was a significant relationship between the existence of ponds and the incidence of HDF in the working area of Tikala Baru health center. From the result of analysis, the score of $\mathrm{OR}=1.359$ and $95 \% \mathrm{CI}=$ 0.146-1.885, therefore, the existence of ponds was a risk factor, meaning that someone who has a pool would 1.3 times more likely to have HDF compared to people who did not have a pool.

Biological eradication of larvae of Aedes aegypti can be done by maintaining larvae fish (tin head fish, gupi fish, and others). The condition of clean water reservoirs that did not fulfill the requirements to support the occurrence of dengue disease, where clean water reservoirs that did not close tightly were a potential place for the breeding of the Aedes aegypti mosquito because the mosquitoes were free to enter.

\section{The effect of education on the incidence of HDF}

The result of this study showed that there was an effect of education on the incidence of HDF which was statistically significant in bivariate and multivariate tests. The results showed that subjects who have higher education would reduce the risk of HDF.

Education was a conscious and planned effort to create a learning atmosphere and learning process so that students actively develop their potential to have religious spiritual strength, selfcontrol, personality, intelligence, noble character, and skills needed by themselves and society. Education increased knowledge and understanding of health. The concept of health and pain became strong which influenced the perceptions/views of the way of life and someone's efforts to increase the degree of health (Boekoesoe, 2013).

The social environment has an important role in the transmission of HDF. In an area, if the community has a perception/view of the importance of maintaining cleanliness to prevent dengue disease, it would affect the incidence of HDF in the area (Chahaya, 2003). A study done by Sarwono showed that people with high level of education tend to be more concerned about the health problems they faced and easier to accept new ideas (Sarwono, 1992).

Groups of highly educated people tend to know more about ways to prevent HDF disease, for example, by conducting $\mathrm{MNE}$, $3 \mathrm{M}$ programs, and giving abate powder. Based on research conducted by Arini (2017) in North Rantau Subdistrict, Labuhanbatu Regency, it showed that there was a relationship between education and the incidence of HDF with an OR score of 4.030, which mean that the risk of HDF in low-educated subjects was 4,030 times greater than subjects with high level of education. The result of other study was presented by Ayuningtyas (2012) which stated that there was a significant relationship between the level of education and the eradication of AA mosquito nests in Surakarta. The higher the level of someone's education, the better the eradication behavior of AA mosquito nests in preventing the incidence of HDF. 
According to Prasetyowati et al. (2018), a person's knowledge was influenced by the level of education. The higher a person's education, the easier it would be to absorb and understand various health messages. The health messages including prevention, control and eradication efforts, including the Aedes aegypti mosquito.

\section{The effect of employment on the incidence of $\mathrm{HDF}$}

The result of this study showed that there was an effect of employment on the incidence of HDF which was statistically significant in bivariate and multivariate tests. The result showed that subjects who worked outside the house would reduce the risk of HDF.

According to Dalimuthe, employment can affect community participation in eradicating HDF to prevent the occurrence of HDF disease (Dalimunthe, 2008). The type of employment can play a role in the emergence of the disease, including the work that was often found around the house in the morning and evening would be at risk of being bitten by the Aedes aegypti mosquito. Based on research conducted by Roose (2008) in Bukit Raya, it was known that there was a relationship between employment and the incidence of HDF ( $\mathrm{p}<0,05)$.

\section{The effect of mosquito nest eradi- cation on the incidence of HDF}

The result of this study showed that there was an effect of mosquito nest eradication on the incidence of HDF which was statistically significant in bivariate and multivariate tests. The result showed that family who lived in house mosquito nest eradication effort were less likely to be infected by HDF than family who did not do mosquito nest eradication.

The right HDF control was the termination of the transmission chain with vector control, because vaccines and drugs were still in the research process. Vector control methods included environmental management such as managing or eliminating mosquito breeding habitats that were well known for $3 \mathrm{M}$ plus or HDF MNE movements. The aim of HDF MNE was to control the population of the aedes aegypti mosquito, so that the transmission of HDF can be prevented/reduced. The implementation of MNE should be conducted continuously at the same time as larva check at least once a week (Ministry of Health of Republic of Indonesia, 2012). Because if the water reservoir was not cleaned regularly, it eventually became potential as a breeding place for the aedes aegypti mosquito, therefore, MNE movement was needed (Spiegel et al., 2007).

This result was supported by a study done by Majid, et al (2017) which showed that there was a relationship between the existence of aedes aegypti mosquito larvae with the implementation of $3 \mathrm{M}$ Plus or HDF MNE Movement, namely draining water reservoirs, closing water reservoirs, burying used goods, repairing drains and gutters, sowing abate powder, having fish that eat larvae, installing wire netting, the habit of hanging clothes in the house, seeking adequate lighting and ventilation which can prevent the incidence of HDF (Majid et al., 2017).

This was in line with a study done by Ananda and Hidayatullah (2015) which stated that MNE has a positive correlation with mosquito larva, therefore, it minimized the incidence of HDF. According to a study done by Nurrochmawati (2017) there was an effect of continuity of HDF MNE with the incidence of HDF if the eradication of mosquito nests was conducted, and it was less likely to be affected by HDF. The result of a study done by Al-Dubai et al. (2013) stated that MNE affected the incidence of HDF in Malaysia. 
Journal of Epidemiology and Public Health (2019), 4(3): 156-170

https://doi.org/10.26911/jepublichealth.2019.04.03.02

\section{The effect of village strata/level on the incidence of HDF}

The results showed that the condition of the villages in each strata had a contextual effect on the incidence of HDF by $51.33 \%$. This number was very large from the standard size of the role of thumb $8-10 \%$, the contextual influence was the village strata indicated by multilevel analysis which was important to note.

\section{REFERENCES}

Adyatma, Ishak H, Ibrahim R (2011). Hubungan antara lingkungan fisik rumah, tempat penampungan air dan sanitasi lingkungan dengan kejadian DBD Di Kelurahan Tidung Kecamatan Rappocini Kota Makassar. Makassar: Universitas Hasanuddin.

Affandy I, Hansen, Sunarti S (2018). Hubungan faktor lingkungan fisik (kepadatan rumah, kelembaban) dengan kejadian demam berdarah dengue di wilayah kerja Puskesmas Bengkuring Kota Samarinda Tahun 2017. https://dspace.umkt.ac.id/handle/463.2017/98

Al-Dubai SAR, Ganasegeran K, Alwan MR, Alshagga MA, Saif-Ali R. (2013). Factors affecting dengue fever knowledge, attitudes and practices among selected urban, semi-urban and rural communities in Malaysia. Southeast Asian Journal of Tropical Medicine and Public Health 44, 37-49.

Amrieds ET, Asfian P, Ainurafiq. (2016). Faktor-Faktor Yang Berhubungan Dengan Kejadian Demam Berdarah Dengue (DBD) Di Kelurahan 19 November Kecamatan Wundulako Unnes.

Ananda A F, Hidayatulloh M. (2015). Pemberantasan sarang nyamuk berkorelasi positif dengan keberadaan jentik dj kelurahan bintaro kota mataram. Jurnal Sangkareang Mataram 1, 5458.

Barrera R, Amador M, MacKay AJ. (2011). Population dynamics of aedes aegypti and dengue as influenced by weather and human behavior in san juan, puerto rico. PLoS Neglected Tropical Diseases5.doi:10.1371/journal.pntd.o 001378

Boekoesoe L (2013). Kajian Faktor Lingkungan Terhadap Kasus Demam Berdarah Dengue (DBD) Studi Kasus Di Kota Gorontalo Provinsi Gorontalo. Laporan akhir hibah disertasi doktor: Universitas Negeri. Gorontalo.

Brunkard JM, López JLR, Ramirez J, Cifuentes E, Rothenberg SJ, Hunsperger EA, Moore CG, et al. (2007). Dengue fever seroprevalence and risk factors, Texas-Mexico border, 2004. Emerging Infectious Diseases, 13: 14771483. doi:10.3201/eid1310.061586

Dash AP, Bhatia R, Kalra NL (2012). Dengue in South-East Asia: an appraisal of case management and vector control. Dengue Bull, 36: 1-13.

Dhillon GPS. (2008). Guidelines for clinical management of dengue fever, dengue haemorrhagic fever and dengue shock syndrome. Directorate of NVBDCP, New Delhi, 14. doi:10.1017/CBO9781107415324.004.

Diaz QFA, Ruth AMV, Alfonso JRM, Ronald ARC, María LLG, Ronald G. (2018). Association between the level of education and knowledge, attitudes and practices regarding dengue in the Caribbean region of Colombia. BMC Public Health. BMC Public Health, 18(1). doi: 10.1186/s12889-018-5055$\mathrm{Z}$.

Dinata A, Dhewantara PW (2012). Karakteristik lingkungan fisik, biologi, dan sosial di daerah endemis DBD Kota 
Banjar Tahun 2011. Jurnal Ekologi Kesehatan 11, 315-326.

Francisco F, Kaunang WPJ, Kekenusa JS. (2017). Hubungan antara faktor lingkungan biologis dengan kejadian penyakit demam berdarah dengue (DBD) di wilayah kerja Puskesmas Tikala Manado.

Kemendagri. (2015). Peraturan Menteri Dalam Negeri Nomor 84 Tahun 2015 tentang SOTK Pemerintah Desa. http://www.keuangandesa.com/wp content/uploads/2015/02/Permenda gri-Nomor-84-Tahun-2015-SusunanOrganisasi-dan-Tata-KerjaPemerintah-Desa.pdf

Kementerian Kesehatan RI. (2017). Profil Kesehatan Indonesia 2016. Available at: http://www.depkes.go.id/resources/download/pusdatin/profil-kesehatan-indonesia/Profil-KesehatanIndonesia-2016.pdf

. 2018. Profil Kesehatan Indonesia 2017.http://www.pusdatin.kemkes.go .id/resources/download/pusdatin/pr ofilkesehatan-indonesia/Data-danInformasi_Profil-Kesehatan-Indonesia-2017.pdf

Majid AL, Dwi SD, Muhammad. (2017). Hubungan Jumlah Penghuni, Jumlah Tempat Penampungan Air dan Pelaksanaan 3M Plus dengan Keberadaan Jentik Nyamuk Aedes Sp di Kelurahan Balleangin Kecamatan Balocci Kabupaten Pangkep. Higiene. 3(1) ISSN : 2541-5301

Murti, B. 2013. Desain dan Ukuran Sampel untuk Penelitian Kuantitatif dan Kualitatif di Bidang Kesehatan. Yogyakarta: Gadjah Mada University Press. (2016). Prinsip dan Metode Riset Epidemiologi. Surakarta: Universitas Sebelas Maret. (2018). Prinsip dan Metode Riset
Epidemiologi Edisi ke Empat. Program Studi Ilmu Kesehatan Masyarakat Program Pascasarjana Universitas Sebelas Maret. Bintang Fajar Offset. ISBN: 978-602-71484-2-0.

Nurrochmawati I, Dharmawan R, Pawito . (2017). Biological, Physical, Social, and Environmental Factors Associated with Dengue Hemorrhagic Fever in Nganjuk, East Java. Journal of Epidemiology and Public Health, 2(2).

Phuong HL, Peter JDV, Chaweewon B, Tran QB, Nguyen VN, Piet AK (2008). Dengue Risk Factors And Community Participation In Binh Thuan Province, Vietnam, A Household. Southeast Asian J Trop Med Public Health, 39(1).

Prasetyowati H, Astuti EP, Widawati M (2018). Faktor yang Berhubungan dengan Keberadaan Jentik Aedes aegypti di Daerah Endemis Demam Berdarah Dengue (DBD) Jakarta Barat. doi: 10.22435/blb.v13i2.5804.115-124.

Rendy, Mentary Putry. (2013). Hubungan faktor perilaku dan faktor lingkungan dengan keberadaan larva nyamuk aedes aegypti di Kelurahan Sawah Lama Tahun 2013. Peminatan Kesehatan Lingkungan Program Studi Kesehatan Masyarakat Fakultas Kedokteran Dan Ilmu Kesehatan Universitas Islam Negeri Syarif Hidayatullah Jakarta.

Sarfraz, MS, Nitin KT, Fazlay SF, Usama I B, Asanobu K, Marc S (2014). Mapping urban and peri-urban breeding habitats of Aedes mosquitoes using a fuzzy analytical hierarchical process based on climatic and physical parameters. Geospatial Health, 8(3), doi: 10.4081/gh.2014.297.

Schaff F, Mathis A. (2014). Dengue and 
Journal of Epidemiology and Public Health (2019), 4(3): 156-170

https://doi.org/10.26911/jepublichealth.2019.04.03.02

dengue vectors in the WHO European region: past, present, and scenarios for the future. The Lancet Infectious Diseases 14, 1271-1280. doi:10.1016/S1473-3099(14)70834-5

Soegijanto S (2003). Demam Berdarah Dengue: Tinjauan dan Temuan Baru di Era 2003. Surabaya: Airlangga University Press.

Soetaryo (2004). Dengue. Yogyakarta: Medika Fakultas Kedokteran UGM.38. doi:10.14710/JKLI.13.1.30 - 38

Sukowinarsih, TE, Widya HC. (2010). Hubungan Sanitasi Rumah Dengan Angka Bebas Jentik Aedes Aegypti. Kesehatan Masyarakat 6: 30-35. doi:ISSN 1858-1196

Sunaryo, Nova P (2014). Surveilans Aedes aegypti di Daerah Endemis Demam Berdarah Dengue. Jurnal Kesehatan Masyarakat Nasional 8: 423-429. doi:10.21109/kesmas.v8i8.415

Wati WE (2009). Beberapa faktor yang berhubungan dengan kejadian DBD di Kelurahan Ploso Kecamatan Pacitan Tahun 2009. Program Studi Kesehatan Masyarakat Fakultas Ilmu
Kesehatan Universitas Muhammadyah, Surakarta. doi:10.1017/CBO9781107415324.004

Winarsih S (2014). Hubungan Kondisi Lingkungan Rumah dan Perilaku PSN dengan Kejadian DBD. Unnes Jurnal of Public Health. 2, 2-6. doi:10.15294/UJPH.V2I1.3041

WHO (2009). Dengue: guidelines for diagnosis, treatment, prevention, and control. Special Programme for Research and Training in Tropical Diseases $\mathrm{x}$, 147. doi: WHO/HTM/NTD/DEN/2O09.1

WHO and the Special Programme for Research and Tropical Diseases (TDR). (2012). Treatment, prevention and control global strategy for dengue prevention and control 2.

Yunita J, Mitra S, Herlina (2012). Pengaruh Perilaku masyarakat dan kondisi lingkungan terhadap kejadian demam berdarah dengue. Jurnal Kesehatan Komunitas. 1(4): 105 